\title{
Organo Phosphorus-Selenium Heterocycles Derived from Haloalkanols and Alkenes
}

\author{
Guoxiong Hua, Amy L. Fuller, Alexandra M. Z. Slawin and J. Derek Woollins* \\ EastChem School of Chemistry, University of St Andrews, Fife, KY16 9ST, UK Fax: (+44)-1334-463384 E-mail: jdw3@st-and.ac.uk.
}

Received: The date will be inserted once the manuscript is accepted.

\begin{abstract}
Treating Woollins' reagent (WR) with an equimolar amount of sodium 2-bromoalkanolates (which were prepared in situ from the reaction of bromoalkanol and $\mathrm{NaH}$ ) in THF gave five- or six-membered PSeOC $_{n}(n=2$ or 3$)$ phosphorus-selenium heterocycles $\mathbf{3}$ and $\mathbf{4}$ in good yields. WR reacting with one equivalent of conjugated 1,3-dienes led to the formation of different end products: with 1,4-diphenylbuta-1,3diene giving a five-membered 2,3,5-triphenyl-4-styryl-1,2,5selenadiphospholane 2,5-diselenide 5; however, with 2,3dibenzyl-1,3-butadiene affording 4,5-dibenzyl-2-phenyl-3,6dihydro-2H-1,2-selenaphosphinine 2-selenide 6 as a major isolable product. Refluxing WR with one equivalent of unconjugated 2,5-dimethyl-1,5-hexyldiene in toluene produced $\mathrm{P}$-Se heterocyclic compound 7 with the same five-membered $\mathrm{C}_{2} \mathrm{P}(\mathrm{Se}) \mathrm{SeP}(\mathrm{Se})$ motif as 5. Furthermore, heating a toluene solution of WR with an equimolar amount of $N$-allylaniline gave rise of a five-membered $\mathrm{C}_{2} \mathrm{NP}(\mathrm{Se}) \mathrm{Se}$ heterocycle 8; carrying out a reaction of cinnamonitrile with an equivalent of WR under identical conditions did not give any air-stable product, however, selenoamide $\mathbf{1 1}$ was isolated in $95 \%$ yield after treatment with water. Three demonstrative X-ray structures are reported.
\end{abstract}

Key words: Woollins' reagent; Phosphorus-selenium heterocycles; Alkenes; Haloalkanols; Selenoamide.

Selenium-containing heterocyclic compounds have been attracting considerable attention due in part to their interesting reactivities and potential pharmaceutical properties, ${ }^{1,2}$ applications as new materials $^{3}$ as well as reagents and catalysts. ${ }^{4}$ However, the synthesis of selenium-containing organic heterocycles is not always easy because of the inconvenience of typical selenium reagents such as $\mathrm{H}_{2} \mathrm{Se}$, NaHSe, $\left(\mathrm{Me}_{3} \mathrm{Si}\right)_{2} \mathrm{Se}$, potassium selenocyanate and tetraethylammonium tetraselenotungstate $\left[\mathrm{Et}_{4} \mathrm{~N}\right]_{2} \mathrm{WSe}_{4}$, each exhibiting its own problems including toxicity, solubility, difficulty in handling and poor reactivity. 2,4-Bis(phenyl)-1,3diselenadiphosphetane-2,4-diselenide $\quad[\mathrm{PhP}(\mathrm{Se})(\mu$ $\mathrm{Se})]_{2}$, known as Woollins' reagent, WR, is an efficient selenating reagent in synthetic chemistry. ${ }^{5}$ WR has been widely utilized as a selenation reagent for the synthesis of a wide range of selenium containing and non-selenium containing compounds as well as for the synthesis of a variety of phosphorus-selenium heterocycles. ${ }^{6-15}$ In continuation of our studies investigating the reactivity of WR towards different organic substrates as precursors or building blocks, herein, we report the synthesis and characterization of six small phosphorus-selenium heterocycles and one selenium containing heteroatom compound from the reaction of WR with alkenes or haloalkanols and three representative X-ray structures.
Heating 1-bromoethanol or 1-bromopropanol with equi-molar amount of $\mathrm{NaH}$ in THF at $70{ }^{\circ} \mathrm{C}$ for $2 \mathrm{~h}$, followed by treating with a half-molar amount of WR at room temperature for $24 \mathrm{~h}$ gave the corresponding five- or six-membered phosphorus-selenium heterocycles 3 and $\mathbf{4}$ in $91 \%$ and $86 \%$ yields, respectively (Scheme 1). Apparently, WR reacts with sodium 2-bromoalkanolates first producing the intermediates $\mathbf{1}$ and $\mathbf{2}$ as salts, followed by intramolecular cyclization to give the final products $\mathbf{3}$ and 4. However, when bromoalkanols with long alkene chain $(n \geq 4)$ were used, the reactions were too complex to isolate any pure product.

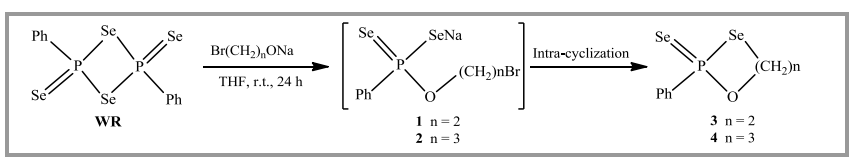

Scheme 1 Synthesis of phosphorus-selenium heterocycles 3 and 4 .

Compounds $\mathbf{3}$ and $\mathbf{4}$ are air and moisture stable for several months without any decomposition, and soluble in normal organic solvents. Compounds 3 and 4 were fully characterised by multinuclear NMR and IR spectroscopy and accurate mass measurement. Both compounds showed the anticipated molecular ion peaks $[\mathrm{M}+\mathrm{H}]^{+}$, and were confirmed by satisfactory accurate mass measurements. ${ }^{31} \mathrm{P}$ NMR spectra of $\mathbf{3}$ and 4 showed sharp singlets at 88.4 and $68.4 \mathrm{ppm}$, respectively flanked by two pairs of selenium satellites with ${ }^{31} \mathrm{P}^{77} \mathrm{Se}$ coupling constants of $390 / 381$ $\mathrm{Hz}$ and $852 / 832 \mathrm{~Hz}$, indicating the presence of both $\mathrm{P}-$ Se single bond and $\mathrm{P}=\mathrm{Se}$ double bonds in these heterocyclic compounds. This was further supported by the ${ }^{17} \mathrm{Se}$ NMR spectra which showed two doublets at $342.5 / 370.4 \mathrm{ppm}$ and $-0.4 /-40.5 \mathrm{ppm}$ with matching ${ }^{31} \mathrm{P}_{-}{ }^{77} \mathrm{Se}$ coupling constants.

Refluxing a toluene solution of 1,4-diphenylbuta1,3-diene with an equimolar amount of WR led to new five-membered 2,3,5-triphenyl-4-styryl-1,2,5selenadiphospholane 2,5-diselenide $\mathbf{5}$ with one $\mathrm{C}=\mathrm{C}$ double bond unreacted in $36.2 \%$ yield via the cleavage of four-membered $[\mathrm{P}(\mathrm{Se})(\mu-\mathrm{Se})]_{2}$ ring as shown in Scheme 2. Carrying on the reaction of $\mathbf{W R}$ with two or more equivalents of 1,4-diphenylbuta-1,3-diene under identical conditions furnished the same product with a slight improvement of yield. Prolonged reactions had no impact on the yield. Furthermore, to investigate the reactivity of the remaining $\mathrm{C}=\mathrm{C}$ double bond in compound $\mathbf{5}$ towards WR, the reaction of compound $\mathbf{5}$ with one equivalent of $\mathbf{W R}$ was performed in refluxing toluene. As expected, no new products were isolated with recovery of the starting 
materials, compounds 5 and WR. The result suggests that the steric hindrance effectively shields the further reaction of $\mathbf{W R}$ with the remaining pendant $\mathrm{C}=\mathrm{C}$ double bond.

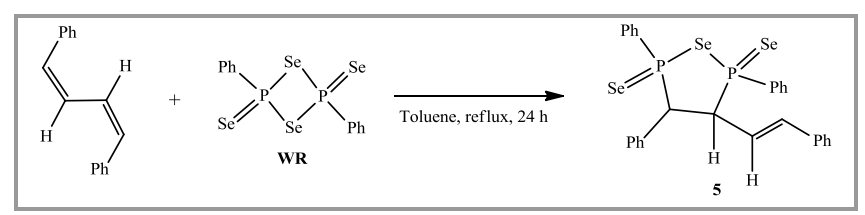

Scheme 2 Synthesis of heterocycle 5 from the selenation of 1,4diphenylbuta-1,3-diene

Surprisingly, WR reacting with an equimolar amount of 2,3-dibenzyl-1,3-butadiene in refluxing toluene led to 4,5-dibenzyl-2-phenyl-3,6-dihydro- $2 \mathrm{H}$ 1,2-selenaphosphinine 2-selenide 6 in $45.6 \%$ yield as a unique product rather than a five-membered ring as compound 5 (Scheme 3). Once again, we carried on the reaction of the product 6 with one more equivalent of WR under identical conditions, but no new product was identified.

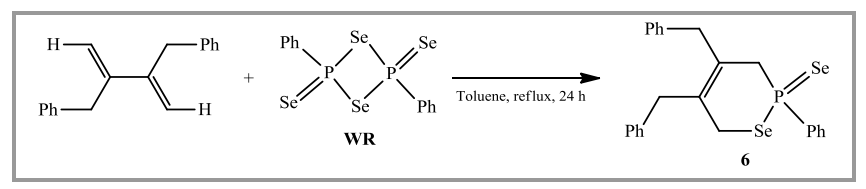

Scheme 3 Synthesis of heterocycle 6 from the selenation of 2,3dibenzyl-1,3-butadiene.

The above results prompted us to investigate related reactions. Unconjugated 2,5-dimethyl-1,5hexyldiene reacted with an equimolar amount of WR in refluxing toluene resulting in a unique P-Se heterocyclic compound 7 with five-membered $\mathrm{C}_{2} \mathrm{P}(\mathrm{Se}) \mathrm{SeP}(\mathrm{Se})$ motif in $46.1 \%$ isolated yield after work-up (Scheme 4). Once more, the remaining unconjugated $\mathrm{C}=\mathrm{C}$ double bond in the heterocycle 7 remained unreacted. The product was further treated with another equivalent of WR under identical conditions leading to recovery of the starting materials.

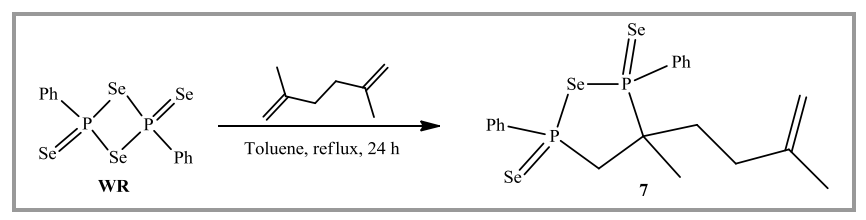

Scheme 4 Synthesis of heterocycle 7 from the selenation of 2,5dimethyl-1,5-hexyldiene

Compounds $5-7$ were spectrally characterised by multinuclear NMR and IR spectroscopy and accurate mass measurement. All of new compounds showed the anticipated molecular ion peaks $[\mathrm{M}+\mathrm{H}]^{+}$, and were confirmed by satisfactory accurate mass measurements. The phosphorus atoms in compounds 5 - 7 are potentially stereogenic centres. In fact, two stereoisomers were observed by multinuclear NMR in compounds 5 and $7 .{ }^{31} \mathrm{P}$ NMR spectra of $\mathbf{5}-\mathbf{7}$ showed sharp singlets in the range of $43.0-61.8 \mathrm{ppm}$, flanked by two pairs of selenium satellites with ${ }^{31} \mathrm{P}^{77} \mathrm{Se}$ coupling constants in the ranges of $333-416 \mathrm{~Hz}$ and $756-803 \mathrm{~Hz}$, indicating the presence of both P-Se single bond and $\mathrm{P}=\mathrm{Se}$ double bond in these heterocyclic compounds. This was further supported by the ${ }^{77}$ Se NMR spectra which showed one set of triplets at 364.1 and $469.1 \mathrm{ppm}$ for $\mathbf{5}$ and 7 respectively and two doublets in the range of $-179.0-$ $-103.1 \mathrm{ppm}$ with matching ${ }^{31} \mathrm{P}-{ }^{77} \mathrm{Se}$ coupling constants, and displayed two pairs of doublets at 286.5 and $-133.6 \mathrm{ppm}$ with matching ${ }^{31} \mathrm{P}-{ }^{77} \mathrm{Se}$ coupling constants in compound $\mathbf{6}$. The IR spectra of compound 6 showed a strong bond at $2009 \mathrm{~cm}^{-1}$, indicating the presence of an unconjugated $\mathrm{C}=\mathrm{C}$ supporting the formation of the six-membered heterocycle.

The X-ray structure of $\mathbf{5}$ is shown in Figure $1^{16}$. The newly formed ring is non-planar and there is a trans arrangement of two phenyl groups being inclined each other by $16.6^{\circ}$ and a trans arrangement of two exo-selenium atoms bonded to the phosphorus atoms. The $\mathrm{P} \cdots \mathrm{P}$ cross-ring distance $(3.27 \AA)$ is approximately midway between the P-P single bond $(2.20 \AA)$ and van der Waal' separation $(3.80 \AA)$. The distances of $\mathrm{P}=\mathrm{Se}$ double bonds [2.0914(16) and 2.0944(17) $\AA]$ and P-Se single bonds [2.273(2) and $2.2768(15) \AA]$ are similar to $\mathrm{P}=\mathrm{Se}$ and $\mathrm{P}$-Se bond lengths previously observed in other related compounds containing the $\mathrm{P}(\mathrm{Se})\left(\mu\right.$-Se) unit. $^{17-19}$

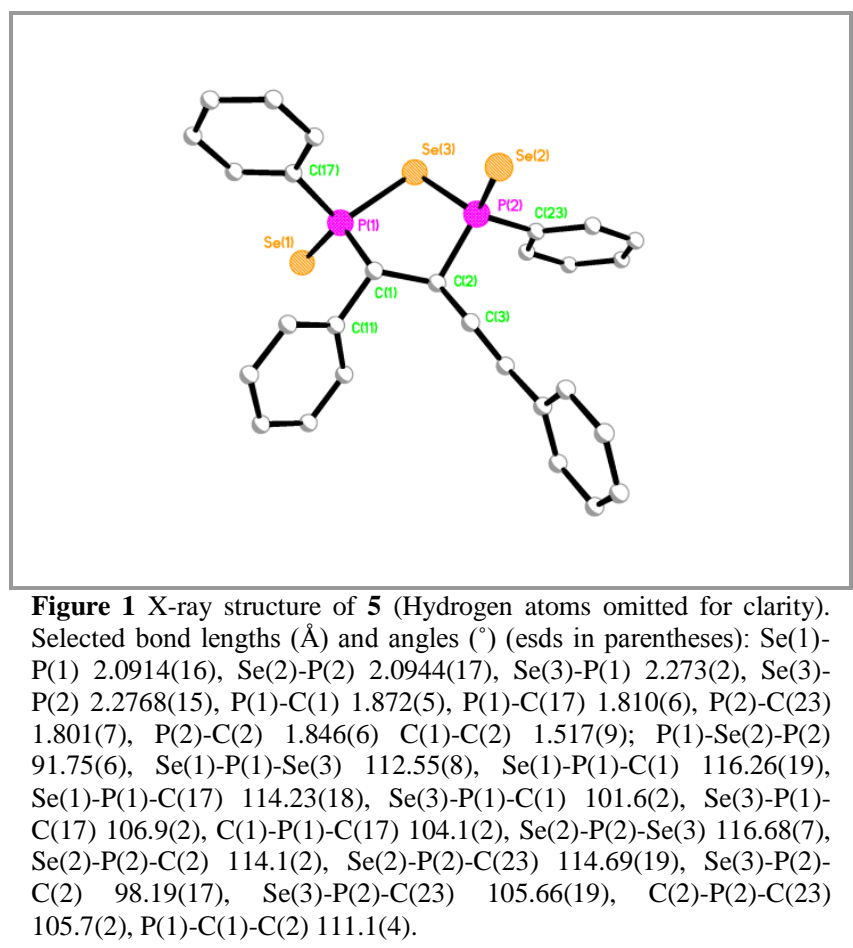


We tested other organic substrates with $\mathrm{C}=\mathrm{C}$ double bonds in reactions with WR. Surprisingly, fivemembered heterocycle $\mathbf{8}$ was obtained in $72 \%$ yield when $\mathrm{N}$-allylaniline reacted with an equivalent of WR in refluxing toluene solution (Scheme 5). Compound 6 represents a symmetric cleavage product of $\mathbf{W R}$ rather than the expected five-membered ring diphosphorus species. A two-step reaction mechanism can be proposed for the formation of $\mathbf{8}$. The first step is that $N$-allylaniline reacts with the true reactive species $\mathrm{PhPSe}_{2}$ (I) from WR in elevated temperature leading to the intermediate II. Then, an intra-molecular [2 + 2] addition resulting in the ring closure of intermediate II gives five-membered heterocycle $\mathbf{8}$.

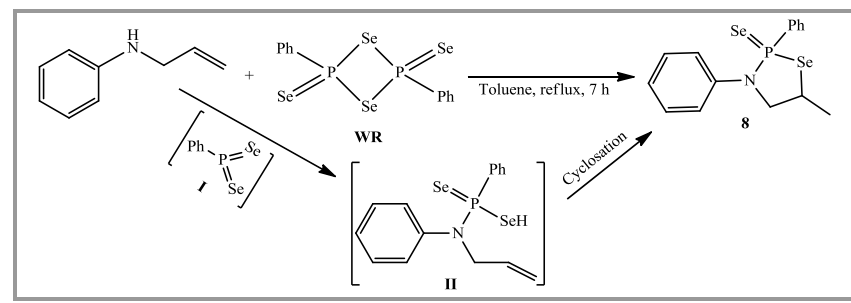

Scheme 5 Synthesis of heterocycle 8 from the selenation of $N$ allylaniline

Treating cinamonitrile with an equivalent of $\mathbf{W R}$ in refluxing toluene did not lead to any stable isolable product. However, when the resulting reaction mixture was treated with water, selenoamide $\mathbf{1 1}$ was isolated in $95 \%$ yield (Scheme 6). We propose that the heterocyclic compound $\mathbf{1 0}$ was readily formed via a [2 +2] cycloaddition of $\mathrm{PhPSe}_{2}$ from WR with the triple bond $\mathrm{C} \equiv \mathrm{N}$ of cinnamonitrile (due to the double bond $\mathrm{C}=\mathrm{C}$ being less reactive than the triple bond $\mathrm{C} \equiv \mathrm{N}$ towards WR). However, the intermediate $\mathbf{1 0}$ is not isolable and easily decomposed to selenoamide $\mathbf{1 1}$ after hydrolysis. This might be following a similar mechanism that suggested in the previous report of the preparation of primary arylselenoamides. ${ }^{19}$

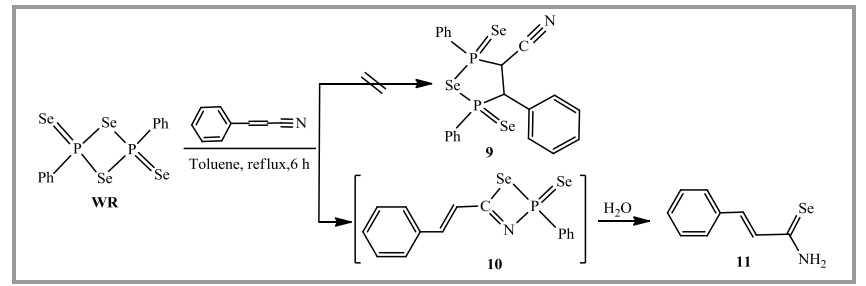

Scheme 6 Synthesis of selenoamide 11 from the selenation of cinnamonitrile

The proposed structures of $\mathbf{8}$ and $\mathbf{1 1}$ are based on their spectral analyses and accurate mass measurement. Both compounds $\mathbf{8}$ and $\mathbf{1 1}$ showed the anticipated molecular ion peaks $[\mathrm{M}+\mathrm{H}]^{+}$, and their formulae were confirmed by satisfactory accurate mass measurements. For 8 , two stereoisomers were found in $c a .2: 1$ intensity ratio in multi-NMR spectra. The ${ }^{31} \mathrm{P}$ NMR spectrum of $\mathbf{8}$ comprises sharp singlets at $60.8 / 59.8 \mathrm{ppm}$, the singlet in each case being flanked by two pairs of selenium satellites with
${ }^{31} \mathrm{P}-{ }^{77} \mathrm{Se}$ coupling constants of $379 / 379 \mathrm{~Hz}$ and 806 / $806 \mathrm{~Hz}$, indicating both $\mathrm{P}-\mathrm{Se}$ single bond and $\mathrm{P}=\mathrm{Se}$ double bond characters. This was further confirmed by the ${ }^{77}$ Se NMR exhibiting double doublets at 482.8 / $465.9 \mathrm{ppm}$ with matching ${ }^{31} \mathrm{P}-{ }^{77} \mathrm{Se}$ coupling constants. For 9, the IR spectra showed a strong band at 1630 $\mathrm{cm}^{-1}$ from the $\mathrm{C}=\mathrm{C}$ double bond, and intense bands at $746 \mathrm{~cm}^{-1}$ and medium bands at $372 \mathrm{~cm}^{-1}$ are characteristic of the $\mathrm{C}=\mathrm{Se}$ group. ${ }^{21}{ }^{77} \mathrm{Se} \mathrm{NMR}$ spectrum displayed a singlet signal at $592.3 \mathrm{ppm}$ which is typical of selenoamides. ${ }^{20,22}$

Compounds 8 and $\mathbf{1 1}$ were crystallized by slow diffusion of hexane into dichloromethane solutions to give transparent, colourless cubic crystals. ${ }^{23} \mathbf{8}$ crystallises in the triclinic space group $P-1$ with two crystallographically independent molecules in the asymmetric unit (Figure 2) and confirms the presence of the five-membered heterocyclic ring. 8 adopts an envelope conformation with the $\operatorname{Se}(1)-\mathrm{P}(2)$ 2.2263(19) [2.2263(19)] $\mathrm{A}^{\circ}$ and $\operatorname{Se}(2)-\mathrm{P}(2) \quad 2.0855(17)$ $[2.0915(17)] \mathrm{A}^{\circ}$ distances being typical of $\mathrm{P}-\mathrm{Se}$ single $\left[2.2-2.3 \mathrm{~A}^{\circ}\right]$ and $\mathrm{P}=\mathrm{Se}$ double bonds $[2.08-2.12$ $\left.\mathrm{A}^{\circ}\right] .{ }^{24,25}$ The $\mathrm{P}-\mathrm{N}$ bond length $[\mathrm{P}(2)-\mathrm{N}(3)$ 1.693(5) $\left.[1.693(6)] \mathrm{A}^{\circ}\right]$ is appropriate for a $\mathrm{P}-\mathrm{N}$ single bond. The geometry around $\mathrm{P}(2) \quad[\mathrm{Se}(1)-\mathrm{P}(2)-\mathrm{Se}(2)$ $114.42(9)[113.99(6)]^{\circ}$ is a distorted tetrahedron due to the steric hindrance of the phenyl groups. One of two phenyl rings is co-planar with the newly formed fivemembered ring with two phenyl rings oriented cis to one another being inclined by $83.2^{\circ}\left[76.8^{\circ}\right]$ to each other.

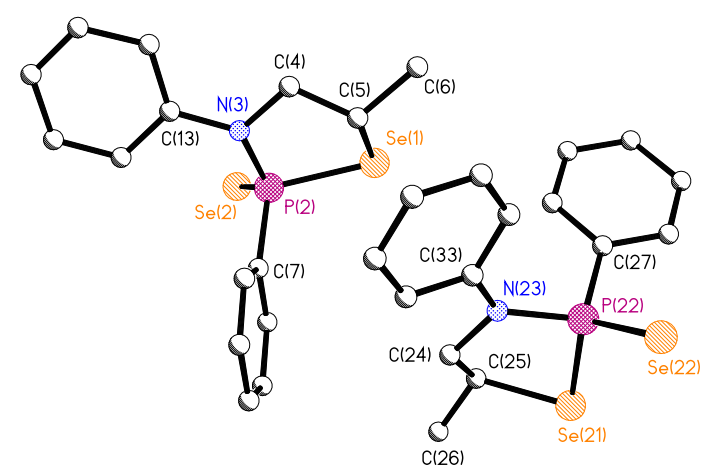

Figure 2. X-ray structure of $\mathbf{8}$ (Hydrogen atoms omitted for clarity). There are two independent molecules in the asymmetric unit. Selected bond lengths $(\AA)$ and angles $\left(^{\circ}\right)$ (esds in parentheses) (dimensions for second independent molecule in square parentheses): $\operatorname{Se}(1)-\mathrm{P}(2)$ 2.2263(19) [2.2263(19)], $\mathrm{Se}(2)-\mathrm{P}(2)$ 2.0855(17) [2.0915(17)], $\mathrm{Se}(1)-$ $\mathrm{C}(5)$ 1.983(8) [1.983(8)], P(2)-N(3) 1.693(5) [1.693(6)], $\mathrm{P}(2)-\mathrm{C}(7)$ 1.797(5) [1.792(6)], N(3)-C(13) 1.424(9) [1.410(8)], N(3)-C(4), 1.472(8) [1.472(8)], C(4)-C(5) 1.462(11) [1.462(11)]; P(2)-Se(1)-C(5) 88.5(2) [88.0(2)], Se(1)-P(2)-Se(2) 114.42(9) [113.99(6)], Se(1)-P(2)$\mathrm{C}(7)$ 106.1(2) [108.6(2)], Se(2)-P(2)-C(7) 111.96(19) [111.8(2)], Se(1)$\mathrm{P}(2)-\mathrm{N}(3)$ 96.5(2) [96.75(16)], $\mathrm{Se}(2)-\mathrm{P}(2)-\mathrm{N}(3)$ 120.06(18) [118.8(2)], $\mathrm{N}(3)-\mathrm{P}(2)-\mathrm{C}(7) \quad 106.0(2) \quad[105.6(2)], \quad \mathrm{P}(2)-\mathrm{N}(3)-\mathrm{C}(4) \quad 117.9(5)$ $[117.3(4)], \quad \mathrm{N}(3)-\mathrm{C}(4)-\mathrm{C}(5) \quad 114.5(5) \quad[115.3(7)], \quad \mathrm{Se}(1)-\mathrm{C}(5)-\mathrm{C}(4)$ $106.7(5)[107.2(5)]$.

Compound 11 crystallises in the monoclinic space group $P 2_{1} / C$ (Figure 3 ) and indicates the presence of 
selenoamide. The $\mathrm{C}=\mathrm{Se}$ double bond length (1.861(7) $\AA)$ is marginally longer that in arylselenoamides $[1.820(4)-1.848(2)]^{20,26,27}$ due to the seleocarbonyl group being stabilised by conjugation with the free electron pairs at the nitrogen and the conjugated $\mathrm{C}=\mathrm{C}$ double bond. A similar $\mathrm{C}=\mathrm{Se}$ double bond distance (1.837(4) $\AA$ ) was found in $N, N$-diethyl-2-methyl-3,3diphenylprop-2-eneselenoamide. ${ }^{28}$ The shortness of the $\mathrm{C}-\mathrm{N}$ bond length in which the $\mathrm{C}-\mathrm{N}$ bonds are adjacent to the $\mathrm{C}=\mathrm{Se}$ double bond [1.337(10) $\AA]$, compared to the normal $\mathrm{C}-\mathrm{N}$ bond distances $[1.45-$ $1.48 \AA],{ }^{20}$ suggests some multiple bonding character. It should be noted that $\mathrm{N}(1)-\mathrm{C}(1)-\mathrm{C}(2)-\mathrm{C}(3)$ adopts is approximately co-planar with the phenyl ring, while Se(1) lies $0.182 \AA$ out of this plane.

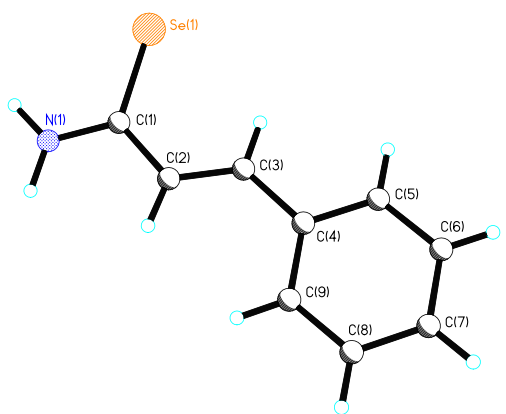

Figure 3. X-ray structure of 11. Selected bond lengths $(\AA)$ and angles $\left(^{\circ}\right)$ (esds in parentheses): $\mathrm{Se}(1)-\mathrm{C}(1) 1.861(7), \mathrm{N}(1)-\mathrm{C}(1) 1.337(10)$, C(1)-C(2) 1.440(12), C(2)-C(3) 1.339(11), C(3)-C(4) 1.446(11); Se(1)-

\section{Experimental Section}

Unless otherwise stated, all reactions were carried out under on oxygen free nitrogen atmosphere using predried solvents and standard Schlenk techniques, subsequent chromatographic and work up procedures were performed in air. ${ }^{1} \mathrm{H}(270 \mathrm{MHz}),{ }^{13} \mathrm{C}(67.9$ $\mathrm{MHz}),{ }^{31} \mathrm{P}-\left\{{ }^{1} \mathrm{H}\right\}(109 \mathrm{MHz})$ and ${ }^{77} \mathrm{Se}-\left\{{ }^{1} \mathrm{H}\right\}(51.4 \mathrm{MHz}$ referenced to external $\left.\mathrm{Me}_{2} \mathrm{Se}\right)$ NMR spectra were recorded at $25^{\circ} \mathrm{C}$ (unless stated otherwise) on a JEOL GSX 270. IR spectra were recorded as $\mathrm{KBr}$ pellets in the range of $4000-250 \mathrm{~cm}^{-1}$ on a Perkin-Elmer 2000 FTIR/Raman spectrometer. Mass spectrometry was performed by the EPSRC National Mass Spectrometry Service Centre, Swansea and the University of St Andrews Mass Spectrometry Service. X-ray crystal data for 5 were collected using Rigaku SCX Mini Mercury CCD system and for $\mathbf{8}$ and $\mathbf{1 1}$ using the Rigaku STANDARD system. ${ }^{29}$ Intensity data were collected using $\omega$ steps accumulating area detector images spanning at least a hemisphere of reciprocal space. All data were corrected for Lorentz polarization effects. Absorption effects were corrected on the basis of multiple equivalent reflections or by semi-empirical methods. Structures were solved by direct methods and refined by full-matrix least-squares against $\mathrm{F}^{2}$ by using the program SHELXTL. ${ }^{30}$ Hydrogen atoms were assigned riding isotropic displacement parameters and
$\mathrm{C}(1)-\mathrm{N}(1) \quad 119.1(6), \quad \mathrm{Se}(1)-\mathrm{C}(1)-\mathrm{C}(2) \quad 123.3(5), \quad \mathrm{N}(1)-\mathrm{C}(1)-\mathrm{C}(2)$ 117.6(7), C(1)-C(2)-C(3) 122.4(7), C(2)-C(3)-C(4) 128.0(7).

Molecules of $\mathbf{1 1}$ pack into a herringbone arrangement with intermolecular N-H..Se hydrogen bonds (H..Se 2.571(5), N...Se 3.44(2) $\AA$, N-H..Se 172.2(6) ${ }^{\circ}$ )

In conclusion, Woollins' reagent (WR) reacting with equimolar amount of sodium 2-bromoalkanolates gave the corresponding five- or six-membered phosphorus-selenium heterocycles in good yields. WR reacting with dienes resulted in the formation of different end products: with conjugated 1,4diphenylbuta-1,3-diene and unconjugated 2,5dimethyl-1,5-hexyldiene affording diphosphorus species heterocyles with a $\mathrm{C} 2 \mathrm{P}(\mathrm{Se}) \mathrm{SeP}(\mathrm{Se})$ motif; however, with 2,3-dibenzyl-1,3-butadiene producing a monophosphorus species heterocyle with a $\mathrm{C} 4 \mathrm{P}(\mathrm{Se}) \mathrm{Se}$ motif. Treating WR with $\mathrm{N}$-allylaniline under identical conditions resulted in a new five-membered $\mathrm{C}_{2} \mathrm{NP}(\mathrm{Se}) \mathrm{Se}$ heterocycle. Reaction of cinnamonitrile with an equivalent of $\mathbf{W R}$ under identical conditions did not give any isolable product apart from selenoamide, which was isolated in $95 \%$ yield after treatment with water. The structures of all new compounds have been elucidated by using ${ }^{1} \mathrm{H},{ }^{13} \mathrm{C}$, ${ }^{31} \mathrm{P},{ }^{77} \mathrm{Se}$ NMR spectroscopy and accurate mass measurement in conjunction with single crystal X-ray crystallography of three structures.

constrained to idealized geometries. These data can be obtained free of charge via www.ccdc.cam.ac.uk/conts/retrieving.html or from the Cambridge Crystallographic Data centre, 12 Union Road, Cambridge CB2 1EZ, UK; fax (+44) 1223-336033; e-mail: deposit@ccdc.cam.ac.uk. CCDC Nos 5 893079; 8 893078; 11893077.

General procedure for the synthesis of heterocyles 3 and 4. A white suspension of 2-bromoalkanol (2.0 $\mathrm{mmol})$ and $0.16 \mathrm{~g}$ of $\mathrm{NaH}(4.0 \mathrm{mmol})$ in $50 \mathrm{~mL}$ of THF was heated at $70^{\circ} \mathrm{C}$ for $2 \mathrm{~h}$. Upon cooling to room temperature and removing unreacted solid, the filtrate was added to $\mathbf{W R}(0.54 \mathrm{~g}, 1.0 \mathrm{mmol})$ and the mixture was stirred at room temperature for $24 \mathrm{~h}$. After removing unreacted solid by filtration and evaporating solvent in vacuo, the residue was purified by column chromatography on silica gel (1:9 ethyl acetate/dichloromethane) to give the compounds $\mathbf{3}$ and 4.

2-Phenyl-1,3,2-oxaselenaphospholane 2-selenide (3): $0.275 \mathrm{~g}$ as a yellow oil (91\% yield). Selected IR $\left(\mathrm{KBr}, \mathrm{cm}^{-1}\right): 1435(\mathrm{~m}), 1259(\mathrm{~m}), 1185(\mathrm{w}), 1100(\mathrm{~s})$, 1016(s), 983(s), 925(m), 745(s), 688(m), 547(s), 549(s), 520(m). ${ }^{1} \mathrm{H}$ NMR $\left(\mathrm{CD}_{2} \mathrm{Cl}_{2}, \delta\right), 8.00-7.87(\mathrm{~m}$, $2 \mathrm{H}, \mathrm{ArH}), 7.52-7.49(\mathrm{~m}, 3 \mathrm{H}, \mathrm{ArH}), 4.82-4.64(\mathrm{~m}, 2 \mathrm{H}$, $\left.\mathrm{OCH}_{2}\right)$, 3.78-3.60 (m, 2H, $\left.\mathrm{SeCH}_{2}\right)$ ppm. ${ }^{13} \mathrm{C} \mathrm{NMR}$ 
$\left(\mathrm{CD}_{2} \mathrm{Cl}_{2}, \delta\right), 136.9(\mathrm{~d}, J(\mathrm{P}, \mathrm{C})=93.0 \mathrm{~Hz}), 133.2(\mathrm{~d}$, $J(\mathrm{P}, \mathrm{C})=3.1 \mathrm{~Hz}), 131.0(\mathrm{~d}, J(\mathrm{P}, \mathrm{C})=12.5 \mathrm{~Hz}), 128.6$ $(\mathrm{d}, J(\mathrm{P}, \mathrm{C})=14.5 \mathrm{~Hz}), 72.7,34.8$ ppm. ${ }^{31} \mathrm{P}$ NMR $\left(\mathrm{CD}_{2} \mathrm{Cl}_{2}, \delta\right), 88.4(\mathrm{~s}, J(\mathrm{P}, \mathrm{Se})=390 \mathrm{~Hz}, J(\mathrm{P}, \mathrm{Se})=852$ $\mathrm{Hz}) \mathrm{ppm} .{ }^{17} \mathrm{Se}$ NMR $\left(\mathrm{CD}_{2} \mathrm{Cl}_{2}, \delta\right), 342.5(\mathrm{~d}, J(\mathrm{P}, \mathrm{Se})=$ $390 \mathrm{~Hz}),-0.4(\mathrm{~d}, J(\mathrm{P}, \mathrm{Se})=852 \mathrm{~Hz}) \mathrm{ppm}$. Accurate mass measurement $\left[\mathrm{EI}^{+}, \mathrm{m} / \mathrm{z}\right]: 303.8773[\mathrm{M}]^{+}$, calculated mass for $\mathrm{C}_{8} \mathrm{H}_{9} \mathrm{OP}^{76} \mathrm{Se}_{2}: 303.8770$.

2-Phenyl-1,3,2-oxaselenaphosphinane 2-selenide (4): $0.280 \mathrm{~g}$ as a yellow oil ( $86 \%$ yield). Selected IR $\left(\mathrm{KBr}, \mathrm{cm}^{-1}\right): 1434(\mathrm{~m}), 1258(\mathrm{~m}), 1183(\mathrm{~m}), 1104(\mathrm{~s})$, 979(vs), 895(m), 864(m), 742(s), 688(m), 583(s), 547(vs), 524(s). ${ }^{1} \mathrm{H}$ NMR $\left(\mathrm{CD}_{2} \mathrm{Cl}_{2}, \delta\right), 8.08-8.00(\mathrm{~m}$, $2 \mathrm{H}, \mathrm{ArH}), 7.55-7.50(\mathrm{~m}, 3 \mathrm{H}, \mathrm{ArH}), 4.90-4.76(\mathrm{~m}, 2 \mathrm{H}$, $\left.\mathrm{OCH}_{2}\right), 4.29-4.14\left(\mathrm{~m}, 2 \mathrm{H}, \mathrm{SeCH}_{2}\right), 3.08-3.02(\mathrm{~m}, 2 \mathrm{H}$, $\left.\mathrm{CH}_{2}\right)$ ppm. ${ }^{13} \mathrm{C}$ NMR $\left(\mathrm{CD}_{2} \mathrm{Cl}_{2}, \delta\right), 135.0(\mathrm{~d}, J(\mathrm{P}, \mathrm{C})=$ $93.4 \mathrm{~Hz}), 133.2(\mathrm{~d}, J(\mathrm{P}, \mathrm{C})=3.1 \mathrm{~Hz}), 131.0(\mathrm{~d}, J(\mathrm{P}, \mathrm{C})$ $=12.5 \mathrm{~Hz}), 128.7(\mathrm{~d}, J(\mathrm{P}, \mathrm{C})=14.5 \mathrm{~Hz}), 68.2,27.1$, $23.7 \mathrm{ppm} .{ }^{31} \mathrm{P}$ NMR $\left(\mathrm{CD}_{2} \mathrm{Cl}_{2}, \delta\right), 68.4(\mathrm{~s}, J(\mathrm{P}, \mathrm{Se})=$ $381 \mathrm{~Hz}, J(\mathrm{P}, \mathrm{Se})=832 \mathrm{~Hz}) \mathrm{ppm} .{ }^{77} \mathrm{Se} \mathrm{NMR}\left(\mathrm{CD}_{2} \mathrm{Cl}_{2}\right.$, $\delta), 370.4(\mathrm{~d}, J(\mathrm{P}, \mathrm{Se})=381 \mathrm{~Hz}),-40.5(\mathrm{~d}, J(\mathrm{P}, \mathrm{Se})=832$ $\mathrm{Hz}) \mathrm{ppm}$. Accurate mass measurement $\left[\mathrm{EI}^{+}, \mathrm{m} / \mathrm{z}\right]$ : $317.8924[\mathrm{M}]^{+}$, calculated mass for $\mathrm{C}_{9} \mathrm{H}_{11} \mathrm{OP}^{76} \mathrm{Se}_{2}$ : 317.8926 .

Synthesis of 2,3,5-triphenyl-4-styryl-1,2,5selenadiphospholane 2,5-diselenide (5). A solution of 1,4-diphenyl-1,3-butadiene $(0.21 \mathrm{~g}, 1.0 \mathrm{mmol})$ and WR $(0.54 \mathrm{~g}, 1.0 \mathrm{mmol})$ in $20 \mathrm{~mL}$ of toluene was refluxed for $24 \mathrm{~h}$. Upon cooling to room temperature, the resulting red suspension was evaporated under reduced pressure and the residue was extracted with dichloromethane $(2 \mathrm{~mL})$ and purified by column chromatography on silica gel (eluent $1: 1$ dichloromethane / hexane) to give $0.235 \mathrm{~g}$ as a dark yellow solid in $36.2 \%$ yield. Two stereoisomers were found in $c a .1: 1$ intensity ratio. Selected IR $(\mathrm{KBr}$, $\left.\mathrm{cm}^{-1}\right): 1657(\mathrm{~m}, \mathrm{C}=\mathrm{C}), 1636(\mathrm{~m}, \mathrm{C}=\mathrm{C}), 1577(\mathrm{~m}, \mathrm{C}=\mathrm{C})$, 1493(w), 1434(m), 1089(s), 956(m), 746(m), 726(m), 689(s), 544(vs), 515(m), 478(m), 417(m), 372(m). ${ }^{1} \mathrm{H}$ NMR $\left(\mathrm{CD}_{2} \mathrm{Cl}_{2}, \delta\right), 8.40-8.33(\mathrm{~m}, 4 \mathrm{Hx} 2, \mathrm{ArH}), 7.61(\mathrm{~d}$, $2 \mathrm{Hx} 2, \mathrm{ArH}), 7.35-6.88(\mathrm{~m}, 14 \mathrm{Hx} 2, \mathrm{ArH}), 5.98(\mathrm{~d}$, $1 \mathrm{Hx} 2, \mathrm{CH}), 5.12(\mathrm{~m}, 1 \mathrm{Hx} 2, \mathrm{CH}), 4.57(\mathrm{~m}, 2 \mathrm{Hx} 2, \mathrm{CH})$ ppm. ${ }^{13} \mathrm{C}$ NMR $\left(\mathrm{CD}_{2} \mathrm{Cl}_{2}, \delta\right), 136.6,136.4,133.6$, $133.5,130.0,130.9,130.5,130.1,129.0,128.8,128.5$, $128.4,127.9,127.6,126.8,126.4,121.4,121.1,121.0$, $120.9,56.5,56.9,30.1,29.9,29.8,29.6 \mathrm{ppm} .{ }^{31} \mathrm{P}$ NMR $\left(\mathrm{CD}_{2} \mathrm{Cl}_{2}, \delta\right)$, two phosphorus species were observed: $61.8(\mathrm{~s}, J(\mathrm{P}-\mathrm{Se})=333 \mathrm{~Hz}, J(\mathrm{P}=\mathrm{Se})=803$ $\mathrm{Hz}) ; 56.8(\mathrm{~s}, J(\mathrm{P}-\mathrm{Se})=338 \mathrm{~Hz}, J(\mathrm{P}=\mathrm{Se})=792 \mathrm{~Hz})$ ppm. ${ }^{77} \mathrm{Se}$ NMR $\left(\mathrm{CD}_{2} \mathrm{Cl}_{2}, \delta\right)$, one endo-Se atoms and two exo-Se were observed: $469.1(\mathrm{t}, J(\mathrm{P}-\mathrm{Se})=333$ $\mathrm{Hz}) ;-160.7(\mathrm{~d}, J(\mathrm{P}=\mathrm{Se})=803 \mathrm{~Hz}) ;-179.0(\mathrm{~d}, J(\mathrm{P}=\mathrm{Se})$ $=792 \mathrm{~Hz}) \mathrm{ppm}$. MS $\left(\mathrm{CI}^{+}, \mathrm{m} / \mathrm{z}\right), 661[\mathrm{M}+\mathrm{H}]^{+}$. Accurate mass measurement $\left(\mathrm{CI}^{+}, \mathrm{m} / \mathrm{z}\right): 650.9014[\mathrm{M}+\mathrm{H}]^{+}$, calculated mass for $\mathrm{C}_{28} \mathrm{H}_{25} \mathrm{P}_{2}{ }^{76} \mathrm{Se}_{3}: 650.9002$.

\section{Synthesis of 3-benzyl-2,5-diphenyl-3-(3- phenylprop-1-en-2-yl)-1,2,5-selenadiphospholane 2,5-diselenide (6). A mixture of 2,3-dibenzyl-1,3-} butadiene $(0.24 \mathrm{~g}, 1.0 \mathrm{mmol})$ and WR $(0.54 \mathrm{~g}, 1.0$ $\mathrm{mmol}$ ) in $150 \mathrm{~mL}$ of toluene was refluxed for $24 \mathrm{~h}$. The red suspension disappeared and a yellow solution with some black solid formed. Upon cooling to room temperature, the solvent was removed under reduced pressure and the organic residue was extracted with dichloromethane $(2 \mathrm{~mL})$ and purified by column chromatography on silica gel (eluent dichloromethane) to give $0.315 \mathrm{~g}$ as a pale yellow paste in $62.8 \%$ yield. Selected IR $\left(\mathrm{KBr}, \mathrm{cm}^{-1}\right): 2009$ (vs, C $=\mathrm{C}), 1492(\mathrm{~m}), 1433(\mathrm{~m}), 1090(\mathrm{~s}), 1027(\mathrm{~m})$, 996(m), 730(s), 726(m), 695(s), 537(m), 514(m). ${ }^{1} \mathrm{H}$ NMR $\left(\mathrm{CD}_{2} \mathrm{Cl}_{2}, \delta\right), 7.99-7.92(\mathrm{~m}, 2 \mathrm{H}, \mathrm{ArH}), 7.49-7.46$ (m, 3H, ArH), 7.36-7.03 (m, 10H, ArH), $3.83(\mathrm{~s}, 2 \mathrm{H}$, $\left.\mathrm{CH}_{2}\right), 3.67-3.53\left(\mathrm{~m}, 2 \mathrm{H}, \mathrm{CH}_{2}\right), 3.28-3.01(\mathrm{~m}, 4 \mathrm{H}$, $\left.\mathrm{CH}_{2}\right) \mathrm{ppm} .{ }^{13} \mathrm{C}$ NMR $\left(\mathrm{CD}_{2} \mathrm{Cl}_{2}, \delta\right), 138.9,138.3,138.2$, $136.2,136.0,134.2,133.4,132.6(\mathrm{~d}, J(\mathrm{P}, \mathrm{C})=12.5$ $\mathrm{Hz}), 132.2,132.1,131.8(\mathrm{~d}, J(\mathrm{P}, \mathrm{C})=3.1 \mathrm{~Hz}), 129.1$, $129.0,128.7,128.4(\mathrm{~d}, J(\mathrm{P}, \mathrm{C})=12.5 \mathrm{~Hz}), 126.6(\mathrm{~d}$, $J(\mathrm{P}, \mathrm{C})=12.5 \mathrm{~Hz}), 105.5,45.2(\mathrm{~d}, J(\mathrm{P}, \mathrm{C})=29.1 \mathrm{~Hz})$, $39.4(\mathrm{~d}, J(\mathrm{P}, \mathrm{C})=81 \mathrm{~Hz}), 39.3(\mathrm{~d}, J(\mathrm{P}, \mathrm{C})=83 \mathrm{~Hz})$, $28.3(\mathrm{~d}, J(\mathrm{P}, \mathrm{C})=7.3 \mathrm{~Hz}) \mathrm{ppm} .{ }^{31} \mathrm{P}$ NMR $\left(\mathrm{CD}_{2} \mathrm{Cl}_{2}, \delta\right)$, $48.1(\mathrm{~s}, J(\mathrm{P}-\mathrm{Se})=416 \mathrm{~Hz}, J(\mathrm{P}=\mathrm{Se})=756 \mathrm{~Hz}), 48.0(\mathrm{~s}$, $J(\mathrm{P}-\mathrm{Se})=416 \mathrm{~Hz}, J(\mathrm{P}=\mathrm{Se})=756 \mathrm{~Hz}) \mathrm{ppm} .{ }^{77} \mathrm{Se}$ $\operatorname{NMR}\left(\mathrm{CD}_{2} \mathrm{Cl}_{2}, \delta\right), 286.5(\mathrm{~d}, J(\mathrm{P}-\mathrm{Se})=415 \mathrm{~Hz}),-133.6$ $(\mathrm{d}, J(\mathrm{P}=\mathrm{Se})=756 \mathrm{~Hz}) \mathrm{ppm} . \mathrm{MS}\left(\mathrm{CI}^{+}, \mathrm{m} / \mathrm{z}\right), 503$ $[\mathrm{M}+\mathrm{H}]^{+}$. Accurate mass measurement $\left(\mathrm{CI}^{+}, \mathrm{m} / \mathrm{z}\right)$ : $502.9941[\mathrm{M}+\mathrm{H}]^{+}$, calculated mass for $\mathrm{C}_{24} \mathrm{H}_{23} \mathrm{PSe}_{2} \mathrm{H}$ : 502.9946 .

\section{Synthesis of 3-methyl-3-(3-methylbut-3-en-1-yl)-} 2,5-diphenyl-1,2,5-selenadiphospholane 2,5diselenide (7). A suspension of 2,5-dimethyl-1,5hexyldiene $(0.11 \mathrm{~g}, 1.0 \mathrm{mmol})$ and WR $(0.54 \mathrm{~g}, 1.0$ $\mathrm{mmol}$ ) in $20 \mathrm{~mL}$ of toluene was refluxed for $24 \mathrm{~h}$. The red suspension disappeared and a yellow solution with some black solid formed. The solvent was removed in vacuo and the organic residue was purified by column chromatography on silica gel (eluent $1: 1$ hexane / dichloromethane) to give $0.260 \mathrm{~g}$ as a reddish yellow oil in $46.1 \%$ yield. Two stereoisomers were found in ca. 2 : 3 intensity ratio. Selected IR $\left(\mathrm{KBr}, \mathrm{cm}^{-1}\right)$ : 1660(m, C=C), 1658(m, C=C), 1435(s), 1378(m), 1308(m), 1091(s), 1021(m), 844(m), 817(m), 741(s), 688(s), 563(s), 522(s). ${ }^{1} \mathrm{H}$ NMR $\left(\mathrm{CD}_{2} \mathrm{Cl}_{2}, \delta\right), 8.14-$ 8.08 (m, 4Hx2, $\mathrm{ArH}), 7.52-7.48$ (m, 6Hx2, $\mathrm{ArH}), 5.40$ $\left(\mathrm{d}, J(\mathrm{P}, \mathrm{H})=10.2 \mathrm{~Hz}, 2 \mathrm{Hx} 2, \mathrm{CH}_{2}\right), 4.81-4.73(\mathrm{~m}$, $\left.2 \mathrm{Hx} 2, \mathrm{CH}_{2}\right), 4.09\left(\mathrm{~s}, 1 \mathrm{H}, \mathrm{CH}_{2}\right), 4.07\left(\mathrm{~s}, 1 \mathrm{H}, \mathrm{CH}_{2}\right)$, $4.05\left(\mathrm{~s}, 1 \mathrm{H}, \mathrm{CH}_{2}\right), 4.03\left(\mathrm{~s}, 1 \mathrm{H}, \mathrm{CH}_{2}\right), 1.99(\mathrm{~s}, 3 \mathrm{H}$, $\left.\mathrm{CH}_{3}\right), 1.95\left(\mathrm{~s}, 3 \mathrm{H}, \mathrm{CH}_{3}\right), 1.75-1.70\left(\mathrm{~m}, 2 \mathrm{Hx} 2, \mathrm{CH}_{2}\right)$, $1.56\left(\mathrm{~s}, 3 \mathrm{H}, \mathrm{CH}_{3}\right), 1.54\left(\mathrm{~s}, 3 \mathrm{H}, \mathrm{CH}_{3}\right), \mathrm{ppm} .{ }^{13} \mathrm{C} \mathrm{NMR}$ $\left(\mathrm{CD}_{2} \mathrm{Cl}_{2}, \delta\right), 138.7,138.5,132.6,131.9,131.6,131.5$, $128.5,128.3,123.4,122.7,58.4,57.3,55.0,54.7$, $46.5,44.4,33.4,33.1,25.7,25.5,18.9,18.1 \mathrm{ppm} .{ }^{31} \mathrm{P}$ NMR $\left(\mathrm{CD}_{2} \mathrm{Cl}_{2}, \delta\right), 43.8(\mathrm{~s}, J(\mathrm{P}-\mathrm{Se})=366 \mathrm{~Hz}, J(\mathrm{P}=\mathrm{Se})$ $=760 \mathrm{~Hz}), 43.0(\mathrm{~s}, J(\mathrm{P}-\mathrm{Se})=380 \mathrm{~Hz}, J(\mathrm{P}=\mathrm{Se})=760$ $\mathrm{Hz}) \mathrm{ppm} .{ }^{77} \mathrm{Se} \mathrm{NMR}\left(\mathrm{CD}_{2} \mathrm{Cl}_{2}, \delta\right), 364.1(\mathrm{t}, J(\mathrm{P}-\mathrm{Se})=$ 
$367 \mathrm{~Hz}),-103.1(\mathrm{~d}, J(\mathrm{P}=\mathrm{Se})=760 \mathrm{~Hz}),-110.5(\mathrm{~d}$, $J(\mathrm{P}=\mathrm{Se})=760 \mathrm{~Hz}) \mathrm{ppm} . \mathrm{MS}\left(\mathrm{CI}^{+}, \mathrm{m} / \mathrm{z}\right), 565[\mathrm{M}+\mathrm{H}]^{+}$. Accurate mass measurement $\left(\mathrm{CI}^{+}, \mathrm{m} / \mathrm{z}\right): 565.9007$ $[\mathrm{M}+\mathrm{H}]^{+}$, calculated mass for $\mathrm{C}_{20} \mathrm{H}_{25} \mathrm{P}_{2} \mathrm{Se}_{3}: 565.9013$.

\begin{abstract}
Synthesis of 5-methyl-2,3-diphenyl-1,3,2selenazaphospholidine 2-selenide (8). A mixture of $N$-allylaniline $(0.135 \mathrm{~g}, 1.0 \mathrm{mmol})$ and WR $(0.54 \mathrm{~g}$, $1.0 \mathrm{mmol}$ ) in $10 \mathrm{~mL}$ of dry toluene was refluxed for 7 $\mathrm{h}$. The red suspension disappeared and a brown solution was formed. After removing the solvent in vacuum the residue was purified by silica gel column (toluene as eluent) to give $0.288 \mathrm{~g}$ as a pale yellow solid in $89.7 \%$ yield. Selected IR $\left(\mathrm{KBr}, \mathrm{cm}^{-1}\right)$ : $1595(\mathrm{~s}$, $\mathrm{C}=\mathrm{C}), 1490(\mathrm{~s}), 1435(\mathrm{~s}), 1267(\mathrm{~s}), 1248(\mathrm{~s}), 1091(\mathrm{~s})$, 880(s), 757(s), 688(vs), 608(s), 526(s), 491(s). Two stereoisomers were found in $c a .2: 1$ intensity ratio. ${ }^{1} \mathrm{H}$ NMR $\left(\mathrm{CD}_{2} \mathrm{Cl}_{2}, \delta\right), 8.14-8.05$ (m, 2Hx2, $\left.\mathrm{ArH}\right)$, 7.52-7.48 (m, 3Hx2, ArH), 7.22-6.61 (m, 5Hx2, ArH), 5.37-5.17 (m, 1Hx2, CH), 4.42-3.75 (m, $\left.2 \mathrm{Hx} 2, \mathrm{CH}_{2}\right)$, 1.90-1.67 (m, 3Hx2, $\left.\mathrm{CH}_{3}\right)$ ppm. ${ }^{13} \mathrm{C}$ NMR $\left(\mathrm{CD}_{2} \mathrm{Cl}_{2}\right.$,

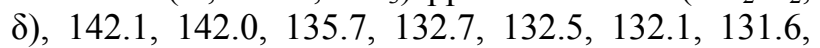
$131.5,131.4,131.3,128.9,128.8,128.5,128.4,128.3$, 124.3, 124.2, 123.1, 122.7, 63.2, 63.1, 41.3, 41.2, 21.0, 18.3 ppm. ${ }^{31} \mathrm{P}$ NMR $\left(\mathrm{CD}_{2} \mathrm{Cl}_{2}, \delta\right), 60.8(\mathrm{~s}, J(\mathrm{P}-\mathrm{Se})$ $=379 \mathrm{~Hz}, J(\mathrm{P}=\mathrm{Se})=806 \mathrm{~Hz}) ; 59.8(\mathrm{~s}, J(\mathrm{P}-\mathrm{Se})=379$ $\mathrm{Hz}, J(\mathrm{P}=\mathrm{Se})=806 \mathrm{~Hz}) \mathrm{ppm} .{ }^{77} \mathrm{Se} \mathrm{NMR}\left(\mathrm{CD}_{2} \mathrm{Cl}_{2}, \delta\right)$, $482.8(\mathrm{~d}, J(\mathrm{P}-\mathrm{Se})=379 \mathrm{~Hz}) ; 465.9(\mathrm{~d}, J(\mathrm{P}-\mathrm{Se})=379$ $\mathrm{Hz}) ;-20.7(\mathrm{~d}, J(\mathrm{P}=\mathrm{Se})=806 \mathrm{~Hz}) ;-83.6(\mathrm{~d}, J(\mathrm{P}=\mathrm{Se})=$ $806 \mathrm{~Hz}) \mathrm{ppm}$. MS $\left(\mathrm{CI}^{+}, \mathrm{m} / \mathrm{z}\right), 322[\mathrm{M}+\mathrm{H}]^{+}$. Accurate mass measurement $\left(\mathrm{CI}^{+}, \mathrm{m} / \mathrm{z}\right): 322.0260[\mathrm{M}+\mathrm{H}]^{+}$, calculated mass for $\mathrm{C}_{15} \mathrm{H}_{17} \mathrm{NPSe}_{2}$ : 322.0264 .
\end{abstract}

Synthesis of 3-phenylprop-2-eneselenoamide (11). A mixture of trans-cinnamonitrile $(0.13 \mathrm{~g}, 1.0 \mathrm{mmol})$ and WR $(0.54 \mathrm{~g}, 1.0 \mathrm{mmol})$ in $20 \mathrm{~mL}$ of toluene was refluxed for $6 \mathrm{~h}$. The red suspension disappeared and a red solution was formed. Upon cooling to $90^{\circ} \mathrm{C}, 1.0$ $\mathrm{mL}$ of water was added and the mixture was refluxed for another $1 \mathrm{~h}$. After cooling to room temperature the solvent was removed in vacuo and the organic residue was extracted with dichloromethane and purified by column chromatography on silica gel (1: 5 ethyl acetate / dichloromethane as eluent) to afford $0.200 \mathrm{~g}$ as a red solid in $95.2 \%$ yield. Selected $\mathrm{IR}\left(\mathrm{KBr}, \mathrm{cm}^{-1}\right)$ : 1664(m, C=C), 1630(vs, C=C), 1426(vs), 1292(m), 1250(m), 1019(m), 968(s), 746(vs), 688(s), 372(m) . ${ }^{1} \mathrm{H}$ NMR $\left(\mathrm{CD}_{2} \mathrm{Cl}_{2}, \delta\right), 8.35$ (dw, 2H, NH), 7.84-7.38 $(\mathrm{m}, 5 \mathrm{H}, \mathrm{ArH}), 6.88(\mathrm{~d}, J(\mathrm{H}, \mathrm{H})=7.0 \mathrm{~Hz}, 1 \mathrm{H}, \mathrm{CH})$, $5.90(\mathrm{~d}, J(\mathrm{H}, \mathrm{H})=7.0 \mathrm{~Hz}, 1 \mathrm{H}, \mathrm{CH}) \mathrm{ppm} .{ }^{13} \mathrm{C} \mathrm{NMR}$ $\left(\mathrm{CD}_{2} \mathrm{Cl}_{2}, \delta\right), 202.4,144.9,130.5,129.3,129.2,128.4$, $128.0 \mathrm{ppm} .{ }^{77} \mathrm{Se}$ NMR $\left(\mathrm{CD}_{2} \mathrm{Cl}_{2}, \delta\right), 592.3 \mathrm{ppm}$. MS $\left(\mathrm{ES}^{+}, \mathrm{m} / \mathrm{z}\right), 233 \quad[\mathrm{M}+\mathrm{Na}]^{+}$. Accurate mass measurement $\left(\mathrm{ES}^{+}, \quad \mathrm{m} / \mathrm{z}\right): 233.9795[\mathrm{M}+\mathrm{Na}]^{+}$, calculated mass for $\mathrm{C}_{9} \mathrm{H}_{9} \mathrm{NSeNa}$ : 233.9798.

Supporting Information for this article is available online at http://www.thiemeconnect.com/ejournals/toc/synlett.

\section{Acknowledgment}

The authors are thankful to the University of St Andrews for financial support and the EPSRC National Mass Spectrometry Service Centre (Swansea) for mass spectral measurements.

\section{References and notes}

(1) T. Wirth, Organoselenium Chemistry: Modern Development in Organic Synthesis, Springer, Berlin, 2000.

(2) (a) P. C. Srivastava, R. K. Robin, J. Med. Chem. 1983, 26, 445-448. (b) Y. Kumar, R. Green, K. Z. Borysko, D. S. Wise, L. Wotring, L. B. Townsend, J. Med. Chem. 1993, 36, 3843-3848. (c) M. Koketsu, H. Hishihara, W. Wu, K. Murakami, I, Saiki, Eur. J. Pharm. Sci. 1999, 9 , 156-161. (d) W. Wu, K. Murakami, M. Koketsu, Y. Yamada, I. Saiki, Anticancer Res. 1999, 19, 53755381(e) B. M. Gai, A. L. Stein, J. A. Roehrs, F. N. Bilheri, C. W. Nogueira and G. Zeni, Org, Biomol. Chem, 2012, 10, 798-807.

(3) (a) J. Garin, Adv. Heterocycl. Chem. 1995, 62, 249-304 (b) T. Uemoto, Adv. Heterocycl. Chem. 1995, 62, 323339.

(4) (a) Organoselenium Chemistry. A practical Approach (Ed.: T. G. Back), Oxford University Press, Oxford 1999. (b) J. Mlochowski, Phosphorus, Sulfur, Silicon 1998, 191, 136-138. (c) M. Tiecco, Top. Curr. Chem. 2000, 208, 7-54. (d) T. Wirth, Angew. Chem. Int. Ed. 2000, 39, 3742-3751. (e) J. Mlochowski, M. Brzaszcz, M. Giurg, J. Palus, H. Wojtowicz, Eur. J. Org. Chem. 2003, 4329-4339.

(5) (a) I. Baxter, A. F. Hill, J. M. Malget, A. J. P. White, D. J. Williams, Chem. Commun. 1997, 2049-2050. (b) A. F. Hill, J. M. Malget, Chem. Commun. 1996, 1177-1178. (c) P. Bhattacharyya, J. D. Woollins, Tetrahedron Lett. 2001, 42, 5949-5951. (d) P. Bhattacharyya, A. M. Z. Slawin, J. D. Woollins, Inorg. Chem. Commun. 2004, 7 , 1171-1173. (e) J. Bethke, K. Karaghiosoff, L. A. Wessjohann, Tetrahedron Lett. 2003, 44, 6911-6913.

(6) G. Hua, J. D. Woollins. Angew. Chem. Int. Ed. 2009, 48, 1368-1377. J.D.Woollins, Synlett, 2012, 23, 1154-1169.

(7) G. Hua, J. B. Henry, Y. Li, A. R. Mount, A. M. Z. Slawin, J. D. Woollins, Org. Biomol. Chem. 2010, 8, 1655-1660.

(8) G. Hua, Y. Li, A. L. Fuller, A. M. Z. Slawin, J. D. Woollins, Eur. J. Org. Chem. 2009, 1612-1618.

(9) G. Hua, A. L. Fuller, Y. Li, A. M. Z. Slawin, J. D. Woollins, New J. Chem. 2010, 34, 1565-1571.

(10) G. Hua, A. L. Fuller, A. M. Z. Slawin, J. D. Woollins, Eur. J. Org. Chem. 2010, 2707-2615.

(11) G. Hua, A. L.Fuller, A. M. Z. Slawin, J. D. Woollins, Polyhedron 2011, 30, 805-808.

(12) G. Hua, A. L.Fuller, A. M. Z. Slawin, J. D. Woollins, Eur. J. Org. Chem. 2011, 3067-3073.

(13) G. Hua, J. M. Griffin, S. E. Ashbrook, A. M. Z. Slawin, J. D. Woollins, Angew. Chem. Int. Ed. 2011, 50, 41234126.

(14) G. Hua. D. B. Cordes, Y. Li, A. M. Z. Slawin, J. D. Woollins, Tetrahedron Lett. 2011, 52, 3311-3314. G. Hua, A. M. Z. Slawin and J. D. Woollins, Synlett 2012, $23,1170-1174$ 
(15) M. J. Pilkington, A. M. Z. Slawin, D. J. Williams, P. T. Wood, J. D. Woollins, Heteroatom Chem. 1990, 1, 351355.

(16) Crystallographic data for compound 5: $\mathrm{C}_{28} \mathrm{H}_{24} \mathrm{P}_{2} \mathrm{Se}_{3}, M$ $=659.33$, Monoclinic, space group $\mathrm{P} 2_{1 / \mathrm{c}}, a=13.065(3)$, $b=19.737(3), c=11.192(2) \AA, \beta=112.23(4), U=$ 2671.4(9) $\AA^{3}, Z=4, \mu=1.639 \mathrm{~mm}^{-1}, 16123$ reflections, 4685 unique $\left(R_{\text {int }}=0.061\right) ; R_{1}=0.0659, w R_{2}$ $=0.1073$.

(17) P. Bhattacharyya, A. M. Z. Slawin, and J. D. Woollins, J. Organomet. Chem. 2001, 623, 116-119.

(18) (a) P. Bhattacharyya, A. M. Z. Slawin and J. D. Woollins, Chem. Eur. J. 2002, 8, 2705-2711. (b) P. Bhattacharyya, A. M. Z. Slawin and J. D. Woollins, Dalton Trans. 2001, 300-303. (c) P. Bhattacharyya, J. Novosad, J. R. Phillips, A. M. Z. Slawin, D. J. Williams and J.D. Woollins, Dalton Trans. 1995, 1607-1613.

(19) J. T. Shore, W. T. Pennington, M. C. Noble and A. W. Cordes, Phosporus, Sulfur Silicon Relat. Elem. 1988, 39, 153-157.

(20) G. Hua, Y. Li, A. M. Z. Slawin, J. D. Woollins, Org. Lett. 2006, 8, 5251-5254.

(21) (a) A. Ogawa, J. Miyaka, Y. Karasaki, S. Murai, N. Sonoda, J. Org. Chem. 1985, 50, 384-386. (b) A. Z. AlRubaie, L. L. Yousif, A. J. H. Al-Hamad, J. Organomet. Chem. 2002, 656, 274-280.

(22) Y. Li, G. Hua, A. M. Z. Slawin, J. D. Woollins, Molecules 2009, 14, 884-892.

(23) Crystallographic data for compound 8: $\mathrm{C}_{15} \mathrm{H}_{16} \mathrm{NPSe}_{2}, M$ $=399.19$, Triclinic, space group P-1, $a=8.785(4), b=$ 9.7406(19), $c=19.590(11) \AA, \alpha=76.22(4), \beta=$ 87.46(5), $\gamma=69.26(4), U=1521.2(11) \AA^{3}, Z=4, \mu=$ $1.743 \mathrm{~mm}^{-1}, 16169$ reflections, 5291 unique $\left(R_{\text {int }}=\right.$ $0.043) ; R_{1}=0.0515, w R_{2}=0.1389$; Crystallographic data for compound 11: $\mathrm{C}_{9} \mathrm{H}_{9} \mathrm{NSe}, M=210.14$, Monoclinic, space group P $2_{1 / \mathrm{c}}, a=20.158(10), b=$ 5.509(3), $c=7.846(4) \AA, \beta=98.756(12), U=861.1(8)$ $\AA^{3}, Z=4, \mu=1.621 \mathrm{~mm}^{-1}, 4686$ reflections, 1509 unique $\left(R_{\text {int }}=0.055\right) ; R_{1}=0.0628, w R_{2}=0.2568$.

(24) S. Parveen, P. Kilian, A. M. Z. Slawin, J.D.Woollins, Dalton Trans. 2006, 2586-2590.

(25) P. Kilian, A. M. Z. Slawin, J. D. Woollins, Chem. Commun. 2001, 2288-2289.

(26) P. A. Otten, S. Gorter, A. van der Gen, Chem. Ber. 1997, 130, 49-54.

(27) G. Hua, Q. Zhang, Y. Li, A. M. Z. Slawin, J. D. Woollins, Tetrahedron 2009, 65, 6074-6082.

(28) H. Fischer, U. Gerbing, A. Triliomis, G. Mueller, B. Huber, J. Riede, J. Hofmann, P. Burger, Chem. Ber. 1988, 121, 2095-2102.

(29) A. L. Fuller, L. A. S. Scott-Hayward, Y. Li, M. Bühl, A. M. Z. Slawin, J. D. Woollins, J. Am. Chem.

Soc. 2010, 132, 5799-5802.

(30) G. M. Sheldrick, SHELXL97, Acta Cryst. 2008, A64, 112-122. 


\section{Reactions Of Woollins' Reagent}

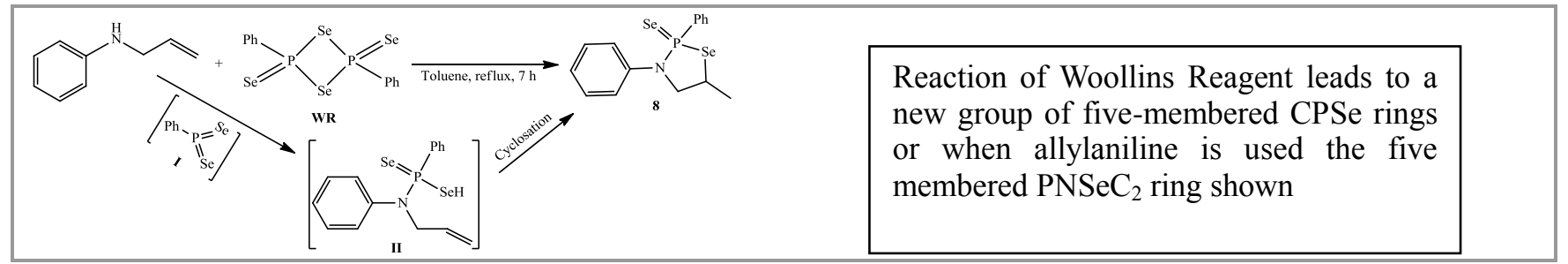

\section{- Statement of significance of work.}

This work describes a new entry into a range of CPSe Rings via simple reactions with WR.

- Full mailing address, telephone, and fax numbers and e-mail address of the corresponding author.

- Graphical abstract.

$\cdot 5$ key words.

- Original Word file.

- Word file saved as a PDF file.

- Original graphics files.

Send all materials on this list to the appropriate Regional Editor. Keep the original Word and graphics files for revisions and for final submission after acceptance. 